\title{
URGENSI DAN SIGNIFIKANSI PENDIDIKAN ISLAM BERWAWASAN MULTIKULTURAL
}

\author{
Mohamad Tulus ${ }^{1}$
}

\begin{abstract}
Multicultural Approach in Islamic Education is necessity. It is a paradigm and method to digs various potential of ethnic and cultural of nation, and embodies in an appropriate conflict management. Multicultural Approach in Islamic Education is wisdom to responding and anticipating the negative impact of globalization that coercing the homogenization and hegemony of patterns and lifestyle. Through Multicultural Approach, Islamic education is expected able to transform inclusifism value so student have open minded about nation that appreciate the diversity of Indonesia.
\end{abstract}

Keywords: Islamic Education, Multicultural.

\section{A. Pendahuluan}

Islam sebagai agama yang universal, mengajarkan kepada umat manusia mengenai berbagai aspek kehidupan, baik duniawi maupun ukhrawi. Salah satu diantara ajaran islam tersebut adalah mewajibkan kepada umat islam untuk melaksanakan pendidikan, karena menurut ajaran islam pendidikan adalah merupakan kebutuhan hidup manusia yang mutlak harus dipatuhi, demi untuk mencapai kesejahteraan dan kebahagiaan dunia akhirat. (Zuhairini, 1995: 98).

Pendidikan menurut pandangan islam adalah merupakan bagian dari tugas kehalifahan manusia yang harus dilaksanakan secara bertanggung jawab. Kemudian pertanggung jawaban itu baru bisa dituntut kalau ada aturan dan pedoman pelaksanaan, oleh karenanya islam tentunya memberikan garisgaris besar tentang pelaksanaan pendidikan tersebut. Islam memberikan konsep-konsep yang mendasar tentang pendidikan, dan menjadi tanggung jawab manusia untuk menjabarkan dengan mengaflikasikan konsep-konsep dasar tersebut dalam peraktek kependidikan. (Zuhairini, 1995: 148).

1 Dosen Fakultas Ilmu Tarbiyah Dan Keguruan Universitas Islam Negeri Maulana Malik Ibrahim Malang Jl. Gajayana No. 50 Malang 65144 
Dengan pendidikan manusia bisa mempertahankan kekahalifahannya sebagaimana pendidikan adalah hal pokok yang membedakan antara manusia dengan makhluk yang lainya. Dan pendidikan yang diberikan atau di pelajari harus dengan nilai-nilai kemanusiaan sebagai mediasi nilai-nilai kemanusiaan itu sendiri. Hal ini dalam agama sangatlah diperhatikan. Akan tetapi dalam pengaflikasiannya yang dilakukan oleh umatnya kadang melenceng dari esensi ajaran agam itu sendiri. Hal inilah yang harus menjadi perhatian dasar pendidikan islam.

Dengan demikian, ajaran islam sarat dengan nilai-nilai, bahkan konsep pendidikan. Akan tetapi semua itu masih bersifat subyektif dan transendental, agar menjadi sebuah konsep yang obyektif dan membumi perlu didekati dengan keilmuan, atau sebaliknya perlu disusun konsep yang obyektif, teori, atau ilmu pendidikan dalam menggunakan paradigma islam yang serat dengan nilai-nilai pendidikan. (Abddurahman Masud, 2001: 19)

Pemikiran semacam ini kiranya saat ini memiliki momentum yang tepat karena dunia pendidikan sedang menghadapi krisis konseptual. (Abddurahman Masud, 2001: 20) Disamping karena begitu cepatnya terjadi perubahan sosial yang sulit di prediksi, dalam konteks untuk menemukan konsep pendidikan islam ideal, maka menjadi tanggung jawab moral bagi setiap pakar pendidikan untuk membangun teori pendidikan islam sebagai paradigma. Paradigma secara etimologi berasal dari bahasa inggris paradigm berarti type of something, model, (bentuk sesuatu, model, pola) lihat Homby, advanced learners pictionary of curent, englis, fourth edition. (AS : oxford University pres, 1989: 895)

Saat ini ada kecenderungan pendidikan Islam kian mendapat tantangan seiring berkembangnya zaman, namun pada sisi lain muncul persaingan global dunia pendidikan islam. Pada satu sisi menjanjikan masa depan pembentukan kualitas anak didik, namun pada sisi lain memunculkan kekhawatiran kian merosotnya kualitas pendidikan yang merusak nilainilai pendidikan Islam itu sendiri.

Pendidikan di tengah medan kebudayaan (culture area), berproses merajut dua substansi ras kultural, yaitu di samping terartikulasi pada upaya pemanusiaan dirinya, juga secara berkesinambungan mewujudkan ke dalam pemanusiaan dunia di sekitarnya. A multicultural country merupakan 
sebutan yang sangat cocok untuk Indonesia. Betapa tidak, keragaman agama dan kepercayaan, bahkan suku yang terpencar di lebih dari 17.000 pulau, keunikan bahasa daerah yang menempati jumlah terbanyak di dunia (lebih dari 500 bahasa daerah) dan sejumlah keragaman lain adalah potensi dan keunikan yang dimiliki oleh bangsa Indonesia sebagai bangsa yang besar. Akan tetapi keragaman dan keunikan tersebut selama ini tidak mendapatkan tempat dalam proses pembangunan, terutama dalam dunia pendidikan.

Paradigma pembangunan pendidikan kita yang sangat sentralistik telah melupakan keragaman yang sekaligus kekayaan dan potensi yang dimiliki oleh bangsa ini. Perkelahian, kerusuhan, permusuhan, munculnya kelompok yang memiliki perasaan bahwa hanya budayanyalah yang lebih baik dari budaya lain adalah buah dari pengabaian keragaman tersebut dalam dunia pendidikan kita.

\section{B. Ajaran Islam Tentang Keberagaman}

Pluralisme keberagamaan atau multikulturalisme merupakan gejala baru dalam sejarah umat manusia. Hal ini, bukkanlah berarti dulu tidak ada wilayah dan budaya-budaya tentang beberapa agama hidup berdampingan. Tetapi kalau dalam satu masyarakat terdapat dua atau tiga agama.- mereka itu berkoeksistensi dalam satu kesatuan paham nilai dan makna yang lebih mendalam. Masing-masing agama mampunyai kedudukan khas,. Yang satu sebagai agama yang dominan berkedudukan di pusat, dan agama-agma lain "sebagai yang diizinkan " di pelbagai pojok rumah besar masyarakat itu.

Dalam masyarakat modern, kesatuan paham nilai-nilai dasar sudah berubah. Masyarkat tidak lagi statis, melainkan dinamis, terus berubah. Maka, kesimbngan-keseimbangan sosial juga berubah, termasuk hubungan sosial tradisional antara agama-agama. Karena kesatuan nilai-nilai dasar sebuah masyarakat tidak dapat diandalkan lagi. Nilai-nilai yang diyakini bersama dalam masyarakat modern perlu dirumuskan secara eksplitis. Bagi bangsa Indenosia, nilai-nilai darsa itu terumuskan dalam pancasila.

Sikap dasar yang memungkinkan adanya beberapa agama hidup berdampingan adalah toleransi.. Mereka membiarkan umat-umat beragama lain, meskipun sering dalam kedudukan sebagai agama-agama yang hanya 
"diizinkan" saja. Hal itu biasanya berlaku terhadap agama-agama dalam wilayah yang direbut.. lebih sulit tolernsi itu dilakukan terhadap agamaagama yang datang kemudian, yang sering dialami sebagai ancaman.

Di level lebih mendalam sikap tolernsi agama mengungkapkan suatu kesadaran mendalam bahwa kepercayaan religius bukan sesuatu yang lahiriah melainkan harus berakar dalam hati yang bersangkutan.

Kiranya dapat dimengerti bahwa langkah dari toleansi ke nondiskriminasi itu membutuhkan waktu sampi dapat dipahami, diterima, dan akhirnya dijunjung tinggi oleh masyarakat karena pada permulaan mesti bersaing dengan penghayatan tradisional bahwa lingkungan hidup religius dan politis merupakan kesatuan. terutama agama yang dominan mudah terancam kalau agama-agama yang secara tradisional dibiarkan mendapat kedudukan resmi yang sama.

Apabila hubunagn saling menghormati antara agama-agama dapat dibangun, hanya tinggal langkah kecil ke sikap yang seakan-akan mengunci hubungan positif itu. Menghomati berarti mengakui secra positif keberadaan pihak lain, termasuk keyakinannya. Menghargai, melebihi sikap hormat, berarti melihat hal-hal positif dalam agama dan kepercayaan orang lain. Berarti mapu belajar satu sama lain. Tentu saja tanpa masuk dalam relatifisme agama.

Kemamuan untuk menghargai, kadang-kadang mengagumi agama lain, akan tetapi tidak mengkompromuikan iman sendiri karena keyakian akan kebenaran agama sendiri tetap dipegang. Tetapi yang teratasi adalah kepicikan pandangan seakan-akan diluar kandang sendiri tidak dapat menumbuhkan suatu yang baik juga. Sikap saling menghormati dan menghargai lalu memungkinkan orang dari agma-gama yang berbeda bersama-sama berjuang demi pembangunan yang sesduai dengan mertabat yang diterima manusia dari Tuhan solidaritas denagn orang-orang kecil, miskin, lemah dan menderita, keadilan sosial., pembebasan dari penindasan dan pemerkosaan berwujud kehidupan yang lebih demokratis, adalah hal-hal yang dapat dilakukan oleh agama-agama secara bahu membahu (Sjadzali, 1995: 128).

Hal ini senada dengan penjelasan yang tercantum dalam al-Quran, surat Al-Hujuraat 
Yang artinya: "Hai manusia, Sesungguhnya Kami menciptakan kamu dari seorang laki-laki dan seorang perempuan dan menjadikan kamu berbangsa - bangsa dan bersuku-suku supaya kamu saling kenal-mengenal. Sesungguhnya orang yang paling mulia diantara kamu disisi Allah ialah orang yang paling taqwa diantara kamu. Sesungguhnya Allah Maha mengetahui lagi Maha Mengenal.

Dari ayat diatas ajaran Islam dengan jelas menggambarkan bahwa toleransi adalah salah satu nilai yang harus diajarkan sebagai bentuk untuk menghargai keberagaman.

\section{Keberagaman Dalam Tinjauan Sejarah}

Para pemeluk ketiga agama ibrani yakni Islam, Yahudi, dan Keristen telah hidup bersama dalam suasana yang relatif damai dibawah naungan hukum Islam selama 460 tahun hampir separuh millennium (Amstrong, 2004: 11).

Terdapat banyak teori berkenaan dengan respons umat beragama terhadap realitas pluralisme atau kebinekaan agama-agama.

Ninian Smart misalnya,mencatat adanya lima cara pandang atau sikap keagamaan dalam merespon kebinekaan agama. Pertama, ekslusivisme absolut, yaitu cara pandang keagamaan yang melihat kebenaran sebagai hanya terdapat dalam tradisi agama sendiri, sedangkan agama lain dianggap sebagai tidak benar; Kedua, relativisme absolute, yaitu cara pandang keagaman yang melihat bahwa berbagai system kepercayaan agama tidak dapat dibandingkan satu sama lain, karena orang harus menjadi "orang dalam" untuk dapat mengerti kebenaran masing-masing agama; Ketiga, inklusivisme hegemonistik, yaitu cara pandang keagaman yang melihat ada kebenaran dalam agama lain, namun menyatakan prioritas terhadap agama sendiri; Keempat, pluralisme realistik, yaitu cara pandang keagaman yang melihat semua agama sebagai jalan yang berbeda-beda (berbagai versi) dari satu kebenaran yang sama; dan yang Kelima, pluralisme regulative, yaitu cara pandang keagaman yang melihat bahwa sementara agama meiliki nilai-nilai dan kepercayaan masing-masing yang mengalami suatu evolusi hsitoris dan perkembangan ke arah suatu kebenaran bersama, hanya saja kebenaran bersama tersebut belum terdefinisikan. 
Sedangkan Komarudin Hidayat menyebutkan lima tipologi sikap keagamaan, yaitu eklusivisme, inklusivisme, pluralisme, eklektivisme, dan universalisme. Eklusivisme adalah sikap keagaman yang memandang bahwa ajaran yang paling benar hanyalah agama yang dipeluknya, sedangkan agama yang lainya sesat. Inklusivisme adalah sikap keagaman keagaman yang berpandangan bahwa diluar agama yang dipeluknya, juga terdapat kebenaran meskipun tidak seutuh dan sesempurna agam yang dianutnya. Pluralisme adalah sikap keagaman yang berpandangan bahwa cara teologis, pluralitas gama dipandang sebagai suatu realitas niscaya yang masingmasing berdiri sejajar sehingga semangat misionaris dan dakwah dianggap "tidak relevan". Eklektivisme adalah sikap keagaman yang berusaha memilih dan mempertemukan berbagai segi ajara agama yang dipandang baik dan cocok untuk dirinya sehingga format akhir dari sebuah agama menjadi semacam mozaik yang bersifat eklektik. Sedangkan universalisme adalah sikap keagaman yang berpandangan bahwa pada dasarnya semua agama adalah satu dan sama. Hanya factor histories-antropologis, agama kemudian tampil dalam format plural.

Secara ringkas teori diatas dapat dikategorikan kepada tiga bentuk respon atau sikap keagaman, yaitu eksklusivisme, inklusivisme dan pluralisme atau multikulturalisme. Eksklusivisme adalah cara pandang keagaman yang menganggap agamanya sebagai satu-satunya jalan keselamatan; inklusivisme adalah cara pandang atau paradigma keagaman yang menganggap bahwa agamanya yang paling benar, tampa mengingkari sksistensi kebenran pada agama lain, karena asal atau sumber agama yang sama. Sedang pluralisme adalah paradigma keagaman yang menyatakan setiap agama mempunyai jalan keselamatannya sendiri, yang pada akhirnya memiliki kesejajaran agama.

\section{Pengertian Multikultural}

Multikultural secara sederhana dapat dipahami sebagai pengakuan, bahwa sebuah Negara atau masyarakat adalah beragam dan majemuk. Sebaliknya, tidak ada satu negarapun yang mengandung hanya kebudayaan nasional tunggal. Dengan demikian, Multikultural merupakan sunnatullah yang tidak dapat ditolak bagi setiap Negara-bangsa di dunia ini. 
Multikultural dapat pula dipahami sebagai "kepercayaan" kepada normalitas dan penerimaan keragaman. Pandangan dunia multicultural seperti ini dapat dipandang sebagai titik tolak dan fondasi bagi kewarganegaraan yang berkeadaban. Disini, multicultural dapat dipandang sebagai landasan budaya (Cultural Basis) tidak hanya bagi kewargaan dan kewarganegaraan, tetapi juga bagi pendidikan.

Multikultural ternyata bukanlah suatu pengertian yang mudah. Di dalamnya mengandung dua pengertian yang sangat kompleks yaitu "multi" yang berarti plural, "kultural" berisi pengertian kultur atau budaya. Istilah plural mengandung arti yang berjenis-jenis, karena plural bukan berarti sekedar pengakuan akan adanya hal-hal yang berjenis-jenis tetapi juga pengakuan tersebut mempunyai imnplikasi-implikasi politis, social, ekonomi. Oleh sebab itu pluralisme berkaitan dengan prinsip-prinsip demokrasi.

Multikultural secara sederhana dapat dikatakan pengakuan atas pluralisme budaya. Pluralisme budaya bukanlah suatu yang "given" tetapi merupakan suatu proses internalisasi nilai-nilai di dalam suatu komunitas.

Dalam tiga dasawarsa ini, kebijakan yang sentralistis dan pengawalan yang ketat terhadap isu perbedaan telah menghilangkan kemampuan masyarakat untuk memikirkan, membicarakan dan memecahkan persoalan yang muncul dari perbedaan secara terbuka, rasional dan damai. Kekerasan antar kelompok yang meledak secara sporadis di akhir tahun 1990-an di berbagai kawasan di Indonesia menunjukkan betapa rentannya rasa kebersamaan yang dibangun dalam Negara-Bangsa, betapa kentalnya prasangka antara kelompok dan betapa rendahnya saling pengertian antar kelompok. Konteks global setelah tragedi September 11 dan invasi Amerika Serikat ke Irak serta hiruk pikuk politis identitas di dalam era reformasi menambah kompleknya persoalan keragaman dan antar kelompok di Indonesia.

Sejarah menunjukkan, pemaknaan secara negatif atas keragaman telah melahirkan penderitaan panjang umat manusia. Pada saat ini, paling tidak telah terjadi 35 pertikaian besar antar etnis di dunia. Lebih dari 38 juta jiwa terusir dari tempat yang mereka diami, paling sedikit 7 juta orang terbunuh dalam konflik etnis berdarah. Pertikaian seperti ini terjadi dari 
Barat sampai Timur, dari Utara hingga Selatan. Dunia menyaksikan darah mengalir dari Yugoslavia, Cekoslakia, Zaire hingga Rwanda, dari bekas Uni Soviet sampai Sudan, dari Srilangka, India hingga Indonesia. Konflik panjang tersebut melibatkan sentimen etnis, ras, golongan dan juga agama.

Pandangan dunia "Multikultural" secara substantif sebenarnya tidaklah terlalu baru di Indonesia. Sebagai Negara-negara yang menyatakan kemerdekaannya sejak lebih setengah abad silam, Indonesia sebenarnya telah memiliki dan terdiri dari sejumlah kelompok etnis, budaya, agama, dan lain-lain, sehingga Negara-bangsa Indonesia secara sederhana dapat disebut sebagai masyarakat "Multikultural".

Realitas sosial masyarakat Indonesia semacam itu sangat sulit dipungkiri dan diingkari. Untuk itu, keragaman, atau kebhinekaan atau multikultural merupakan salah satu realitas utama yang dialami masyarakat dan kebudayaan di masa silam, lebih-lebih lagi pada masa kini dan mendatang.

\section{E. Pendekatan Multikultural dalam Pendidikan Islam : Urgensi dan Signifikansi}

Pendidikan Multikultural adalah suatu keniscayaan. Ia merupakan paradigma dan metode untuk menggali potensi keragaman etnik dan kultural nusantara, dan mewadahinya dalam suatu manajemen konflik yang memadai. Pendidikan multikultural merupakan kearifan dalam merespon dan mengantisipasi dampak negatif globalisasi yang memaksakan homogenisasi dan hegemoni pola dan gaya hidup. Ia juga jembatan yang menghubungkan dunia multipolar dan multikultural yang mencoba direduksi isme dunia tunggal kedalam dua kutub saling berbenturan antara BaratTimur dan Utara-Selatan (Baidhawy, 2005: 17).

Selama ini, pendidikan di Indonesia sedikit menyentuh persoalan bagaimana menghargai kepercayaan-kepercayaan keagamaan dan keragaman kultural yang sangat kaya. Ada kecenderungan Homogenisasi yang diintrodusir secara sistematik melalui dunia pendidikan dibawah payung kebudayaan nasional, hegemoni kebudayaan jawa sebagai pusat dan kebudayaan lain sebagai pinggiran, dan pemiskinan budaya dengan meringkas keragaman identitas kultural sejumlah propinsi. Proses 
homogenisasi, hegemoni dan pemiskinan budaya itu diajarkan dalam Civic education, seperti pancasila, penataran P4 dan bahkan Pendidikan agama (religious education).

Memang pergeseran-pergeseran sosial tersebut merupakan sesuatu yang lumrah karena tidak dikenal sebelumnya. Masing-masing komunitas menutup dirinya sendiri dan mempunyai suatu persatuan semu yang dipaksakan. Kita lihat sebelumnya didalam pendidikan multikultural tidak ada pengelompokan-pengelompokan komunitas yang mengagungkan nilainilai kelompok sendiri tetapi yang mengenal akan nilai-nilai hidup budaya/ komunitas yang lain. Oleh sebab pendidikan multikultural tidak akan dikenal adanya fanatisme atau fundamentalisme sosial-budaya termasuk agama, karena masing-masing komunitas mengenal dan menghargai perbedaan-perbedaan yang ada.

Setidaknya ada empat alasan utama mengapa Multikultural harus diakomodir dalam system pendidikan kewarganegaraan umumnya, dan Pendidikan Agama khususnya. Diantaranya adalah sebagai berikut :

\section{Realitas Bangsa yang sangat Plural.}

Kekayaan akan keanekaragaman-agama, etnik, dan kebudayaan ibarat pisau bermata dua. Di satu sisi kekayaan ini merupakan khazanah yang patut dipelihara dan memberikan nuansa dan dinamika bagi bangsa, dan dapat pula merupakan titik pangkal perselisihan, konflik vertikal dan horizontal.

Perbedaan kelompok-kelompok keagamaan, kelompok etnik, dan kelompok sosiso-kultural yang semakin meningkat dari segi ukuran dan signifikansi politiknya dalam beberapa tahun terakhir, telah melahirkan tuntutan agar kebijakan dan program-program sosial responsif terhadap kebutuhan dan kepentingan keragaman tersebut. Memenuhi tuntutan ini akan menghendaki lebih kepekaan kultural (cultural sensitivity), koalisi pelangi dan negosiasi-kompromi secara pluralistik pula. Ketegangan etnik dan kelompok-kelompok kepentingan tertentu dapat diakselerasi, dan akibatnya terjadi persaingan terhadap berbagai sumberdaya yang terbatas seperti lapangan pekerjaan, perumahan, kekuasaan politik, dan sebagainya. 
Permasalahan pokok yang dihadapi para pendidik dan pergerakan sosial-keagamaan pada era kemajemukan dan era multikurtural adalah bagaimana agar masing-masing tradisi keagamaan tetap dapat mengawetkan, memelihara, melanggengkan, mengalihgenerasikan, serta mewariskan kepercayaan dan tradisi yang diyakini sebagai suatu kebenaran yang mutlak, namun pada saat yang sama juga menyadari sepenuhnya keberadaan kelompok tradisi keagamaan lain yang juga berbuat serupa. Selain memperkuat identitas diri dan kelompoknya, upaya apa yang dilakukan para pendidik sosial keagamaan dalam masing-masing tradisi untuk juga menjaga kebersamaan, kohesi sosial, dan keutuhan bersama? Jika disadari perlunya hal tersebut, lalu apa implikasi dan konsekuensi dari cara, metode, pilihan materi, serta teknik pendidikan dan pengajaran agama yang disajikan kepada masyarakat yang bercorak plural-majemuk-terbuka seperti sekarang ini? Masih adakah "ruang" untuk berpikir sejanakdan berdiskusi bersama kelompok-kelompok yang ada ditengah-tengah masyarakat majemuk dan multikultural ini? Apa pilihan-pilihan yang akan diambil? Jika tidak ada pilihan, apa implikasinya? Jika ada, apa pula konsekwensinya (Abdullah, 2011: 2-3).

Semua persoalan krusial tersebut tidak akan terpecahkan tanpa meninggalkan konsep masyarakat majemuk atau plural dan beralih ke konsep masyarakat multikultural.

\section{Pengaruh Budaya dan Etnisitas terhadap Perkembangan Manusia}

Dalam banyak cara etnisitas dapat dipandang sebagai fenomena persepsi diri (self-perception): suatu komunitas etnik adalah komunitas yang mempercayai dirinya sebagai memiliki asal-usul etnik yang sama. Berbagai kebiasaan-kebiasaan kultural yang sama, mempunyai nenek moyang yang sama, sejarah dan mitologi bersama.

Kebudayaan membentuk perilaku, sikap dan nilai manusia. Perilaku manusia adalah hasil dari proses sosialisasi, dan sosialisasi selalu terjadi dalam konteks lingkungan etnik dan kultural tertentu. Etnisitas dapat didefinisikan sebagai kesadaran kolektif kelompok yang menanamkan rasa memiliki yang berasal dari keanggotaan dalam komunitas yang terikat oleh keturunan dan kebudayaan yang sama. 
Manusia adalah makhluk sosial yang membawa karakter biologis dan psikologis alamiah sekaligus warisan dari latar belakang historis kelompok etniknya, pengalaman kultural dan warisan kolektif. Ketika seorang pendidik mengklaim bahwa prioritas utamanya adalah memperlakukan semua siswa sebagai umat manusia, tanpa memandang identitas etnik, latar belakang budaya, atau status ekonomi, ia telah menciptakan suatu paradoks. Kemanusiaan seseorang tidak dapat diasingkan dan dipisahkan dari kebudayaan dan etnisitasnya.

Pengaruh budaya dan etnisitas sejak awal telah nyata dan terus menjangkau keseluruhan proses perkembangan dan pertumbuhan manusia.

\section{Benturan Global antar Kebudayaan}

Pemisahan terbesar antara umat manusia dan sumber konflik utama berasal dari kebudayaan atau peradaban. Meskipun negara-bangsa akan menjadi aktor kuat, tetapi konflik utama dalam politik global akan terjadi antar bangsa dan kelompok kebudayaan yang berbeda-beda.

Globalisasi telah melahirkan paradoks. Pemberontakan permanen atas keseragaman dan integrasi. Yang ada adalah budaya bukan negara. Bagian bukan keseluruhan. Sekte bukan agama.

Disamping suku, agama juga merupakan medan pertempuran. Apapun bentuk universalisme yang telah memberi karunia dalam sejarah, seperti monoteisme yahudi, kristen dan islam. Dalam perwujudan modernnya tiga agama besar ini bersifat parokial daripada kosmopolitan.

Dalam proses globalisasi, integrasi pasar dunia, negara-bangsa, dan tekhnologi yang memungkinkan individu, korporasi dan negara-bangsa menjangkau pelosok dunia lebih jauh dalam waktu relatif capat dan biaya lebih murah, juga meninggalkan mereka yang tidak mampu membayar tiket globalisasi.

Karena itu, para pendukung multikultural yakin bahwa penghargaan pada kemajemukan, akan menjawab ketegangan antar kebudayaan. 


\section{Efektivitas Belajar tentang Perbedaan}

Problem efektivitas belajar-mengajar untuk menanamkan kesadaran akan perbedaan. Salah satu premis pendidikan multikultural menyatakan bahwa belajar-mengajar merupakan proses kultural yang terjadi dalam konteks sosial.

Pengalaman Indonesia cukup menunjukkan kegagalan sistem pendidikan dalam rangka mengatasi dan mengelola keragaman agama, etnik dan kultural.

Pendidikan agama termasuk civic-education pada masa lampau sebenarnya juga menyinggung masalah pentingnya kerukunan antarumat beragama, namun lebih bersifat permukaan. Istilah "kerukunan" yang diintrodusir lewat indoktrinasi sangat artifisial, karena tidak mencerminkan dialektika, dinamika apalagi kerjasama.

\section{F. Pembahasan}

Pendidikan Islam menurut Fazlur Rahman bukan sekedar perlengkapan dan peralatan fisik atau kuasi fisik pengajaran seperti buku-buku yang diajarkan ataupun struktur eksternal pendidikan, melainkan sebagai intelektualisme Islam karena baginya hal inilah yang dimaksud dengan esensi pendidikan Islam. Hal ini merupakan pertumbuhan suatu pemikiran Islam yang asli dan memadai, dan yang harus memberikan kriteria untuk menilai keberhasilan atau kegagalan sebuah sistem pendidikan Islam.

Pendidikan Islam dapat mencakup dua pengertian besar. Pertama, Pendidikan Islam dalam Pengertian praktis, yaitu pendidikan yang dilaksanakan di dunia Islam, mulai dari pendidikan dasar sampai perguruan tinggi. Untuk konteks Indonesia, meliputi pendidikan di pesantren, di madrasah (mulai dari Ibtidaiyah sampai Aliyah), dan di perguruan tinggi Islam, bahkan bisa juga pendidikan agam Islam di sekolah (sejak dari dasar sampai lajut atas) dan pendidikan agam Islam di perguruan tinggi umum. Kedua, pendidikan Islam yang disebut dengan intelektualisme Islam. Lebih dari itu, pendidikan islam menurut Rahman dapat juga dipahami sebagai proses untuk menghasilkan manusia (ilmuwan) integrative, yang padanya terkumpul sifat-sifat kritis, kretif, dinamis, inovatif, progresif, adil, jujur, dan sebagainya. Ilmuwan yang demikian itu dharapkan dapat memberikan 
alternatif solusi atas problem-peroblem yang dihadapi oleh umat manusia di muka bumi (Sutrisno, 2006: 170).

Dengan mendasarkan pada al-Qur'an, tujuan pendidikan menurut Fazlur Rahman adalah untuk mengembangkan manusia sedemikian rupa sehingga semua pengetahuan yang diperolehnya akan menjadi organ pada keseluruhan pribadi yang kreatif, yang memungkinkan manusia untuk memanfaatkan sumber-sumber alam untuk kebaikan umat manusia untuk menciptakan keadilan, kemajuan dan keteraturan dunia.

Al-Qur'an memberi keritik keras terhadap pencarian pengetahuan yang merusak nilai-nilai moral. Tanggung jawab pendidikan yang pertama adalah menanamkan pada pikiran-pikiran siswa mereka dengan nilai-nilai moral. Pendidikan Islam didasarkan pada idiologi Islam. Karena itu, pada hakikatnya, pendidikan islam tidak dapat meninggalkan keterlibatannya pada presepsi benar dan salah. Al-Qur'an juga sering kali berbicara tentang konsep berpasangan seperti al-dunya dan al-akhirah. al-dunya bermakna bernilai lebih rendah, sisi kehidupan material, sedikit hasil serta tidak memuaskan. Sementara al-akhirah menunjukan sisi sebaliknya, yakni bernilai lebih tinggi, lebih baik, dan menjadi tujuan dari kehidupan. Nilai tinggi inilah yang menjadi tujuan dari kehidupan, bukan yang lebih rendah. Al-Quran juga menyuruh manusia mempelajari kejadian yang terjadi pada diri sendiri, alam semesta, dan sejarah umat manusia di muka bumi dengan cermat dan mendalam serta mengambil pelajaran darinya agar dapat menggunakan pengetahuannya dengan tepat serta agar tidak mengikuti orang yang berbuat kerusakan. Oleh karena itu, menjadi kewajiban bagi pemegang pemerintahan islam untuk merencanakan pendidikan sedemikian rupa sehingga sikap positif manusia tertanam pada alumni dari system pendidikan itu.

Pendidkan Islam mulai abad pertengahan, menurut Fazlur Rahman, dilaksanakan secara mekanis. Oleh karena itu, pendidikan Islam lebih cenderung pada asfek kognitif daripada asfek afektif dan psikomotorik.

Pendidikan-kata ini juga diletakan kepada islam-telah didefinisikan secara berbeda-beda oleh berbagai kalangan, yang banyak dipengaruhi pandangan dunia masing-masing. Namun, pada dasarnya, semua pandangan yang berbeda itu bertemu dengan kesimpulan awal, bahwa pendidikan merupakan suatu proses penyiapan generasi muda untuk menjalankan 
kehidupan dan memenuhi tujuan hidupnya secara lebih efektif dan efisien.

Seperti yang dikemukan oleh Azyumardi Azara bahwa pendidikan Islam merupakan salasatu aspek saja dari ajaran Islam secara keseluruhan. Karnanya, tujuan pendidikan Islam tidak terlepas dari tujuan hidup manusia dalam islam; yaitu untuk menciptakan pribadi-pribadi hamba Allah yang selalu bertakwa kepada-Nya, dan dapat mencapai kehidupan yang berbahagia didunia dan akhirat. Dalam kontek sosial masyarakat, bangsa dan Negara-maka pribadi yang bertakwa ini menjadi rahmatan lil'alamin, baik dalam sekala kecil maupun besar. Tujuan hidup manusia dalam islam inilah yang dapat disebut juga sebagai tujuan akhir pendidikan Islam (Azyumardi Azara, 1999: 8-9).

Selain tujuan umum itu, tentu terdapat pula tujuan khusus yang lebih spesisfik menjelaskan apa yang ingin di capai melalui pendidikan Islam. Tujuan khusus ini lebih praxsis sifatnya, sehingga konsep pendidikan Islam jadinya tidak sekedar idealisasi ajaran-ajaran islam dalam bidang pendidikan. Dengan kerangka tujuan yang lebih praxsis itu dapat dirumuskan harapan-harapan yang ingin di capai dalam tahap-tahap tertentu proses pendidikan, sekaligus dapat pula dinilai hasil-hasil yang telah dicapai.

Tujuan-tujuan khusus itu tahap-tahap pengusasaan anak didik terhadap bimbingan yang diberikan dalam berbagai aspeknya; pikiran, perasaan, kemauan, intuisi, keterampilan, atau dengan istillah lain kognitif, afektif dan motorik. Dari tahapan-tahapan inilah kemudian dapat di capai tujuantujuan yang lebih terperinci lengkap dengan materi, metode dan system evaluasi. Inilah yang kemudian yang disebut dengan kurikulum, yang selanjutnya diperinci lagi dalam silabus dari berbagai materi bimbingan yang akan diberikan.

Pendidikan dalam ajaran Islam memiliki fungsi membangun Akhlakul karimah. Kendati kelahiran pendidikan agama yang sekarang ini kita kenal menjadi mata pelajaran perlu kiranya ada pembaharuan konsep sebagai salasatu usaha untuk bisa lebih memajukan pendidikan islam itu sendiri. Apabila corak pendidikan agama diberikan secara pluralistik misalnya pandekatan moralitas belaka minus ajaran teknis agama-agama.

Sebagai mana telah dibahas terlebih dahulu tentang pengertian 
pendidikan islam dan pendidikan multicultural, jadi bisa disimpulkan bahwa pendidikan islam multikultural adalah pendidikan islam yang mencakup sikap-sikap saling menghargai dalam menghadapi perbedaan.

Pembentukan masyarakat multikultural Indonesia yang sehat tidak bisa secara taken for granted atau trial and error. Sebaliknya harus diupayakan secara sistematis, programatis, integrated dan berkesinambungan bahkan perlu percepatan. Salah satunya pendidikan multikultural yang diselenggarakan melalui seluruh lembaga pendidikan baik formal maupun nonformal bahkan informal di masyarakat luas.

Kebutuhan urgensi dan akselerasi pendidikan multikultural telah cukup lama dirasakan cukup mendesak bagi negara bangsa majemuk lainnya, menghidupkan dan memantapkan multikulturalisme sebagai modal untuk mewujudkan kesejahteraan rakyat Indonesia.

Azyumardi Azra menjelaskan, di negara Barat pendidikan multikultural menemukan momentum sejak dasawarsa 1970-an, setelah pengembangan pendidikan interkultural. Berhadapan dengan meningkatnya multikulturalisme maka paradigma, konsep dan praktek pendidikan multikultural sekalin relavan.

Pada pihak lain gagasan pendidikan Islam multikultural merupakan suatu hal baru di Indonesia. Meski belakangan ini sudah mulai muncul suara-suara yang mengusulkan pendidikan multikultural tersebut di tanah aiar, tidak berkembang wacana publik tentang subjek ini.

Azyumardi menjelaskan, realitas kultural dan perkembangan terakhir kondisi sosial, politik dan budaya bangsa khususnya sejak reformasi yang penuh dengan gejolak sosio politik dan konflik berbagai level masyarakat membuat pendidikan Islam multikultural terasa makin dibutuhkan.

Multikulturalisme merupakan salah satu realitas utama yang dialami masyarakat dan kebudayaan di masa silam, terlebih saat ini dan di masa mendatang. Multikulturalisme secara sederhana dapat dipahami sebagai pengakuan, sebuah negara atau masyarakat beragam dan majemuk. Sebaliknya tidak ada satu negarapun yang mengandung hanya kebudayaan nasional tunggal.

Penting dicatat, keragaman itu hendaklah tidak diinterprestasikan secara tunggal dan lebih jauh komitmen untuk mengakui keragaman sebagai 
salah satu ciri dan karakter utama masyarakat dan negara bangsa tidak berarti ketercerabutan, relativisme kultural, disrupsi sosial atau konflik berkepanjangan pada setiap komunitas, masyarakat dan kelompok etnis dan rasial.

Malik Fadjar menjelaskan, pendidikan Islam multikultural bukan barang baru dalam praktek pendidikan di tanah air. sejak lama menerapkan sistem pendidikan dari berbagai elemen masyarakat dan bangsa. Hal itu dilakukan bukan saja di daerah yang mayoritas berpenduduk muslim, melainkan pendidikan di tengah masyarakat mayoritas nonmuslim.

Multikulturalisme, bermuara kepada terjadinya kesejahteraan di masyarakat dan bukan sebatas bantuan insidental ketika terjadi bencana. Multikulturalisme meliputi juga spiritualisme agama sehingga menyangkut kehidupan lahiriyah dan batiniyah.

Memperbincangkan pendidikan Islam multikultural, muncul pertanyaan bagaimana pendidikan Islam menghadapi globalisasi. Pendidikan Islam sesungguhnya sudah menerapkan multikulturalisme sejak sangat dini. "Pendidikan Islam mengembangkan multikultural sejak lama, bukan barang baru,." Para pendiri RI berpikiran maju dalam merumuskan Undang Undang Dasar 1945. Pasal 33 tentang demokrasi ekonomi sebuah pikiran maju, namun bagaimana mewujudkan kesejahteraan masyarakat justru di sanalah problemnya.

Sementara itu mengemukakan, di antara masalah untuk mewujudkan masyarakat multikultural berkembangnya faham keagamaan eksklusif yang hanya memandang agamanya yang paling benar dan yang lain salah dan harus ditiadakan, kalau perlu dengan kekerasan.

Kelompok eksklusif seperti ini biasanya ekstrim dan ada pada setiap agama, hanya saja besar kecilnya perkembangan kelompok itu tergantung kepada kesempatan yang diberikan kepadanya," kata Atho Mudzar sambil menambahkan, secara keseluruhan kelompok seperti ini kecil jumlahnya tetapi seringkali nyaring bunyinya sehingga dapat berdampak bagi citra keseluruhan kelompok agama yang bersangkutan dan bagi umat beragama di luarnya (Azra, 2013). 


\section{Multikulturalisme dalam Pendidikan Islam Sebuah Keniscayaan}

Multikultural dapat pula dipahami sebagai "kepercayaan” kepada normalitas dan penerimaan keragaman. Pandangan dunia multicultural seperti ini dapat dipandang sebagai titik tolak dan fondasi bagi kewarganegaraan yang berkeadaban. Disini, multicultural dapat dipandang sebagai landasan budaya (Cultural Basis) tidak hanya bagi kewargaan dan kewarganegaraan, tetapi juga bagi pendidikan.

Multikultural ternyata bukanlah suatu pengertian yang mudah. Di dalamnya mengandung dua pengertian yang sangat kompleks yaitu "multi" yang berarti plural, "kultural" berisi pengertian kultur atau budaya. Istilah plural mengandung arti yang berjenis-jenis, karena plural bukan berarti sekedar pengakuan akan adanya hal-hal yang berjenis-jenis tetapi juga pengakuan tersebut mempunyai imnplikasi-implikasi politis, social, ekonomi. Oleh sebab itu pluralisme berkaitan dengan prinsip-prinsip demokrasi.

Multikultural secara sederhana dapat dikatakan pengakuan atas pluralisme budaya. Pluralisme budaya bukanlah suatu yang "given" tetapi merupakan suatu proses internalisasi nilai-nilai di dalam suatu komunitas.

Dalam tiga dasawarsa ini, kebijakan yang sentralistis dan pengawalan yang ketat terhadap isu perbedaan telah menghilangkan kemampuan masyarakat untuk memikirkan, membicarakan dan memecahkan persoalan yang muncul dari perbedaan secara terbuka, rasional dan damai. Kekerasan antar kelompok yang meledak secara sporadis di akhir tahun 1990-an di berbagai kawasan di Indonesia menunjukkan betapa rentannya rasa kebersamaan yang dibangun dalam Negara-Bangsa, betapa kentalnya prasangka antara kelompok dan betapa rendahnya saling pengertian antar kelompok. Konteks global setelah tragedi September 11 dan invasi Amerika Serikat ke Irak serta hiruk pikuk politis identitas di dalam era reformasi menambah kompleknya persoalan keragaman dan antar kelompok di Indonesia.

Sejarah menunjukkan, pemaknaan secara negatif atas keragaman telah melahirkan penderitaan panjang umat manusia. Pada saat ini, paling tidak telah terjadi 35 pertikaian besar antar etnis di dunia. Lebih dari 38 
juta jiwa terusir dari tempat yang mereka diami, paling sedikit 7 juta orang terbunuh dalam konflik etnis berdarah. Pertikaian seperti ini terjadi dari Barat sampai Timur, dari Utara hingga Selatan. Dunia menyaksikan darah mengalir dari Yugoslavia, Cekoslakia, Zaire hingga Rwanda, dari bekas Uni Soviet sampai Sudan, dari Srilangka, India hingga Indonesia. Konflik panjang tersebut melibatkan sentimen etnis, ras, golongan dan juga agama.

Pandangan dunia "Multikultural" secara substantif sebenarnya tidaklah terlalu baru di Indonesia. Sebagai Negara-negara yang menyatakan kemerdekaannya sejak lebih setengah abad silam, Indonesia sebenarnya telah memiliki dan terdiri dari sejumlah kelompok etnis, budaya, agama, dan lain-lain, sehingga Negara-bangsa Indonesia secara sederhana dapat disebut sebagai masyarakat "Multikultural".

Ismail Faruqi menyebutkan, sebagaimana dikutif oleh Sangkot, bahwa setidaknya ada empat isu pokok yang dipandang sebagai landasan normative pendidikan Islam multikultural, khususnya di bidang keagamaan, yaitu: 1) kesatuan dalam aspek ketuhanan dan pean-Nya (wahyu), 2) kesatuan kenabian, 3) tidak ada paksaan dalam beragama, dan 4) pengakuan terhadap eksistensi agama lain. Semua yang demikian disebut normatif karena sudah merupakan ketetapan Tuhan. Masing-masing klasifikasi didukung oleh teks (wahyu), kendati satu ayat dapat saja berfungsi untuk justifikasi yang lain.Sedangkan masalah-maslah yang muncul dari pendidikan multicultural di Indonesia secara umum ada dua hal, yaitu; pertama, pendidikan multicultural merupakan suatu proses. Artinya, konsep pendidikan multicultural yang baru dimulai dalam dunia pendidikan khususnya di Indonesia memerlukan proses perumusan, refleksi dan tindakan di lapangan sesuai dengan perkembangan konsep-konsep yang fundamental mengenai pendidikan dan hak-hak asasi manusia.Kedua, pendidikan multicultural merupakan suatu yang multifaset. Oleh sebab itu meminta suatu pendekatan lintas disiplin (border crossing) dari para pakar dan praktisi pendidikan untuk semakin memperhalus dan mempertajam konsep pendidikan multicultural yang dibutuhkan oleh masyarakat yang dalam hal ini masyarakat Indonesia.

Konsep dasar dari pendidikan multicultural itu memiliki empat nilai ini (core values), yaitu:

1. Apresiasi terhadap adanya kenyataan pluralitas budaya dalam 
masyarakat.

2. Pengakuan terhadap harkat manusia dan hak asasi manusia.

3. Pengembangan tanggung jawab masyarakat dunia.

4. Pengembangan tanggung jawab manusia dan terhadap planet bumi.

Berdasarkan nilai-nilai inti di atas, maka dapat dirumuskan beberapa tujuan yang berkaitan dengan nilai-nilai inti tersebut, yaitu:

1. Mengembangkan perspektif sejarah yang beragam dari kelompokkelompok masyarakat

2. Memperkuat kesadaran budaya yang hidup di masyarakat.

3. Memperkuat kompetensi intelektual dan budaya-budaya yang hidup di masyarakat

4. Membasmi rarisme, seksisme, dan berbagai jenis prasangka (prejudice).

5. Mengembangkan kesadaran atas kepemilikan planet bumi, dan

6. Mengembangkan ketrampilan aksi social (social action).

Dari uraian di atas kiranya ada beberapa hal yang perlu dikaji dalam penerapan pendidikan Islam multikultural di Indoneisa, yaitu; Pertama, pendidikan multicultural secara inheren sudah ada sejak bangsa Indonesa ini ada. Falsafah bangsa Indonesia adalah bhineka tunggal ika, suku gotong royong, membantu, dan menghargai antar satu dengan yang lainnya, betapa dapat dilihat dalam potret kronologis bangsa ini yang sarat dengan masuknya berbagai suku bangsa asing dan terus berakulturasi dengan masyarakat pribumi.

Kedua, pendidikan multicultural memberikan secercah harapan dalam mengatasi berbagai gejolak maryarakat yang terjadi akhir-akhir ini. Pendidikan multikulural adlah pendidikan ysenantiasa menjunjung tinggi nilai-nilai, keyakinan, heterogenitas, pluralitas, dan keragaman, apapun aspeknya dalam masyarakat.

Ketiga, pendidikan multicultural menentang pendidikan yang berorientasi bisnis. Pada saat ini, lembaga pendidikan baik sekolah atau perguruan tinggi berlomba-lomba menjadikan lembaga pendidikannya 
sebagai sebuah institusi yang mampu menghasilkan income yang besar.

Keempat, pendidikan multicultural sebagai resistensi fanatisme yang mengarah pada berbagai jenis kekerasan. Kekerasan muncul ketika saluran kedamaian sudah tidak ada lagi. Kekerasan tersebut sebagai akibat dari akumulasinya berbagai persoalan masyarakat yang tidak diselesaikan secara tuntas dan saling menerima.

Kurikulum Pendidikan Islam yang berwawasan Multikulturalisme

Sebagaiman yang telah diuraikan diatas, pendidikan multikultural dipahami sebagai suatu pengetahuan yang menanamkan kesadaran diri seseorang akan arti perbedaan antarsesama manusia, berbagai budaya dan nilai-nilai yang terdapat di dalamnya. Dalam pandangan Ali Maksum dan Luluk Yunan Ruhendi (2004; 191-192), ciri-ciri dari pendidikan multikultural adalah: (a) tujuannya membentuk "manusia budaya" dan menciptakan "masyarakat berperadaban" (berbudaya); (b) materinya mengajarkan nilai-nilai luhur kemanusiaan, nilai-nilai bangsa, dan nilai-nilai kelompok etnis (kultural); (c) metodenya demokratis, yang menghargai aspek-aspek perbedaan dan keragaman budaya bangsa dan kelompok etnis (multikulturalis), dan; (d) Evaluasinya ditentukan pada penilaian terhadap tingkah laku anak didik yang meliputi persepsi, apresiasi, dan tindakan terhadap budaya lainnya.

Kurikulum dan materi pendidikan Agama Islam bagaimana pun tidak dapat terlepas dari dimensi perkembangan dan nilai-nilai pendidikan multikultural. Adapun komponen yang termasuk dalam kurikulum pendidikan multikultural antara lain tentang studi etnis, kelompok minoritas, gender, kesadaran kultur, hubungan antarsesama manusia, dan pengklarifikasian nilai-nilai dalam suatu kebudayaan. Hal-hal tersebut termasuk pula mengenai konsep rasisme, perbedaan jenis kelamin, keadilan, diskriminasi, opresi, perbedaan dan semacamnya.

Pendidikan Agama Islam yang terintegrasi dengan spirit pendidikan multikultural perlu segera menampilkan ajaran-ajaran Islam yang toleran dengan menitikberatkan pada pemahaman dan upaya untuk bisa hidup dalam konteks perbedaan agama dan budaya, baik secara individual maupun secara kelompok. Oleh karenanya, dalam upaya pengembangan kurikulum pendidikan agama Islam harus diperhatikan dimensi-dimensi 
berikut ini: Pertama, pembelajaran fiqih dan tafsir al-Qur'an tidak harus bersifat linier, namun menggunakan pendekatan muqāran (perbandingan). Ini menjadi sangat penting, karena siswa tidak hanya dibekali pengetahuan atau pemahaman tentang ketentuan hukum dalam fiqih atau makna ayat yang tunggal, namun juga diberikan pandangan yang berbeda. Tentunya, bukan sekedar mengetahui yang berbeda, namun juga diberikan pengetahuan (argumen-dalil) tentang mengapa bisa berbeda; Kedua, untuk mengembangkan kecerdasan sosial, siswa juga harus diberikan pendidikan lintas agama. Hal ini dapat dilakukan dengan mengadakan dialog antar agama; Ketiga, untuk memahami realitas perbedaan dalam beragama, lembaga-lembaga pendidikan Islam menyelenggarakan program road show lintas agama dengan tujuan untuk menanamkan kepedulian dan solidaritas terhadap komunitas agama lain; Keempat, untuk menanamkan kesadaran spiritual, pendidikan Islam perlu menyelenggarakan program seperti spiritual work camp, yaitu dengan cara mengirimkan siswa untuk tinggal dalam sebuah keluarga selama beberapa hari, termasuk kemungkinan tinggal pada keluarga yang berbeda agama. Dalam program ini, siswa harus melebur serta melakukan aktifitas sebagaimana aktifitas keseharian dalam keluarga tersebut. Tujuannya adalah, agar siswa akan mempunyai kesadaran dan kepekaan untuk menghargai dan menghormati orang lain.

Tidak kalah pentingnya, Pendidikan Islam harus memandang iman yang dimiliki oleh setiap pemeluk agama adalah bersifat dialogis, artinya iman itu bisa didialogkan antara Tuhan dan manusia dan antara sesama manusia. Melalui suasana pendidikan seperti itu, akan terbangun suasana pergaulan dalam kehidupan beragama secara dewasa, tidak ada perbedaan yang berarti, tidak dikenal superior ataupun inferior, serta memungkinkan terbentuknya suasana dialog yang memiliki peluang untuk membuka wawasan spritualitas baru tentang keagamaan dan keimanan masingmasing. Hal ini bisa diajarkan lewat pendidikan akidah yang inklusif. Pengajaran agama seperti itu, menuntut untuk bersikap objektif sekaligus subjektif. Objektif, maksudnya sadar bahwa membicarakan banyak iman secara fair itu tanpa harus meminta pertanyaan mengenai benar atau validnya suatu agama. Subjektif berarti sadar bahwa pengajaran seperti itu sifatnya hanyalah untuk mengantarkan setiap peserta didik memahami dan merasakan sejauh mana keimanan tentang suatu agama itu dapat dirasakan oleh orang yang mempercayainya. 


\section{G. Penutup}

Indonesia adalah Negara yang terdiri dari berbagai macam suku dan agama serta aliran kepercayaan, maka Pendidikan Islam sudah seyogyanya diajarkan dengan menggunakan pendekatan multicultural. Hal ini senada dengan konsep kebangsaan Indonesia yaitu Bhineka Tunggal Ika.

Karena selama ini, pendidikan di Indonesia masih sedikit menyentuh persoalan bagaimana menghargai kepercayaan-kepercayaan keagamaan dan keragaman kultural yang sangat kaya. Ada kecenderungan Homogenisasi yang diintrodusir secara sistematik melalui dunia pendidikan dibawah payung kebudayaan nasional, hegemoni kebudayaan jawa sebagai pusat dan kebudayaan lain sebagai pinggiran, dan pemiskinan budaya dengan meringkas keragaman identitas kultural sejumlah propinsi. Proses homogenisasi, hegemoni dan pemiskinan budaya itu diajarkan dalam Civic education, seperti pancasila, penatarn P4 (dimasa orde baru) dan bahkan Pendidikan agama (religious education), khususnya Pendidikan Islam (Islamic education).

Tujuannya adalah agar dengan pendidikan Islam yang berwawasan multicultural tersebut mampu memberikan wawasan kebangsaan terhadap peserta didik yang pluralistic dan multikulturalistik, sehinggan peserta didik lebih toleran dengan setiap perbedaan yang ada di lingkungannya.

\section{DAFTAR PUSTAKA}

Azyumardi Azra, Pendidikan Agama : Membangun Multikulturalisme Indonesia (Lihat dalam Prakata Buku Pendidikan Agama Berwawasan Multikultural miliknya Zakiyuddin Baidhawy).

Amin Abdullah, Pendidikan Agama Era Multikultural-multireligius, Jakarta:

Pusat Studi Agama dan Peradaban (PSAP) Muhammadiyah.

Azyumardi Azara, Pendidikan Islam tradisi dan moderenisasi menuju millennium baru (Jakarta: PT Logos Wacana Ilmu, 1999).

Azyumardi Azra. Kebutuhan Pendidikan Multikultural. Diakses tanggal 27 Juni 2013 dari www.pelita.com).

Abddurahman Masud, dkk. Paradigma pendidikan islam, cet 1 (Yogyakarta: Pustaka Pelajar, bekerjasama dengan Fakultad Tarbiyah IAIN 
walisongo semarang, 2001).

Departemen Agama RI, Pendidikan Islam pendidikan nasional paradigma baru, (Jakarta : Departeman Agamama RI, 2005).

Karen Armstrong : Perang Suci (Jakarta : PT Serambi Ilmu Semesta, 2004).

Munawir Sjadzali. Kontekstualisasi Ajaran Islam (Jakarta: IPHI, 1995).

Paradigma secara etimologi berasal dari bahasa inggris paradigm berarti type of something, model, (bentuk sesuatu, model, pola) lihat Homby, advanced learners pictionary of curent, englis, fourth edition (AS : oxford University pres, 1989).

Sutrisno, Fazlur Rahman Kajian terhadap Metode, Epistimologi dan Sistem Pendidikan (Yogyakarta : Pustaka Pelajar; 2006).

Zakiyuddin Baidhawy, Pendidikan Agama Berwawasan Multikultural (Jakarta: Erlangga, 2005).

Zuhairini ,dkk. Filsfat pendidikan islam, cet 2 ( jalarta: bunyi aksara, 1995). 
